\title{
JUDGE IAN BORRIN: REMEMBERING A FRIEND OF THE LAW REVIEW
}

\section{Geoff McLay*}

In March, the Law Review lost in Judge Ian Borrin one of its best friends, and the Law Faculty one of its best supporters.

Ian Borrin had already made a considerable contribution to the New Zealand legal community before he became involved with the Law Review through the 1995 campaign for Victoria. He was a Victoria alumnus and had been a litigation partner at Macalister Mazengarb Parkin and Rose. He was appointed to the District Court in 1983 where he became known as a conscientious and sensitive Judge especially in the Family Court. He subsequently became the Head of the Police Complaints Authority in 2001. On his death, others paid tribute to his contributions in these legal roles.

I want to pay tribute to Ian's role in supporting the Law Review and later the New Zealand Journal of Public and International Law, various symposia run under their aegis and later his more general support through the establishment of the Ian Borrin Fellowship.

I first met Ian when he had already agreed to support the Law Review for what at the time seemed a massive contribution of $\$ 200000$ over the first five year period (donations which actually continued for most the last two decades). That initial support enabled us to redesign what was quite an old and somewhat tired looking layout and to replace it with a fresher version and a cover that showcased our new home, the Old Government Buildings. I was a very new Faculty member and always very conscious of not spending more than we should of Ian's donation. My recollection of discussing the plans for the reconfiguration of the Law Review with Ian, however, left me with no doubt that his intention was not that we should be penny pinchers but rather that the best way of making use of his generosity was to use it to produce the best possible product that we could. Over my many years as the Faculty Editor of the Law Review and I know in the term of Nessa Lynch who followed me, we have always been conscious of Ian's desire that we should be the best possible Law Review and that we ought not let simple monetary scarcity prevent us from achieving that aim.

A central part of Ian's donation has always been its use to employ a Student Editor-in-Chief who has taken over much of the editorial role that was previously undertaken by staff members. Over the

* Professor, Faculty of Law, Victoria University of Wellington. 
past 20 years there have been some extraordinary Student Editors-in-Chief who have gone on to make significant achievements in the wider legal world. The involvement of the Student Editor-in-Chief as being the principal editor and the principal organiser of other student editors has allowed us to continue to fulfil Professor McGechan's original aim in establishing the review that it be a cooperative venture between Faculty and students. It has also given some of those students a chance to prove their excellence outside the more competitive environment of law school and the usual run of competitions there.

Over the years it was our custom, and it has continued to be so, that we would invite Ian every year to meet the new incoming crop of student editors, either for lunch or at an evening function. I do not recall Ian ever been anything but delighted to come, nor do I ever recall the students not being delighted to meet him, to talk with him and to be a little bit inspired by somebody who had backed up his general support for the Law School by making a particular contribution to the Law Review from his own money. During these sessions with the student editors, and indeed with the dinners that we held with Ian and later with Ian and Jenny, I came to realise that, for Ian, his donation was not really about the money at all. Rather his involvement was about supporting his Law School and the people who are currently at it to achieve the very best that it could achieve. Working on a law review can be a somewhat lonely experience. It involves a lot of work that many people simply read over the top of. It involves trying to convince authors that they really do need to follow the style guide and that sometimes the expression that they had worked so hard on could be better made. For me, and I know for many others who have worked on the Law Review, that rather invisible job was made considerably easier by the fact that Ian had chosen to recognise us in the way that he had.

At the end of his original undertaking, Ian renewed his support for the Law Review. He agreed to support symposia and the publication of special issues. He took great pride in attending events like the Salmond lecture that preceded "the lost cases project" conference in 2010, and attending the launch of the special issue to mark Professor Angelo's forty years at the Faculty. We knew that he must be really ill last October when he was not able to attend the launch of the special issue in honour of Professor Atkin's fortieth anniversary. It was typical of Ian, however, that, even though he was receiving treatment that day for his illness, he still made the effort to email Bill a note entitled "Your goodself", which Bill was thrilled to be able to read at the function.

Over the course of time Ian's support moved to include the establishment of the Judge Ian Borrin Visiting Fellowship, through which leading scholars are invited to spend a period of time at the Faculty. Over the course of the last five years these visitors have included Lord Collins, Justice Paul Walker from the English High Court, Professor Kent Roach from the University of Toronto, and most recently Professor Peter Mirfield from Jesus College Oxford. Professor Roach's visit was of particular value to me in my role at the Law Commission because we were able to use his expertise in International Security Law as part of our work that led to the report on the use of confidential and 
security information in courts. ${ }^{1}$ One of the most pleasing aspects of these Fellowship visits was that Ian was able to enjoy the company of these scholars and the events that were run around their visits. Some of us were also lucky enough to be invited to the dinners that Ian generously hosted for each of the Fellows. These dinners were a remarkable reflection of Ian's personality. They involved a collection of his family, personal friends, friends in the law, their partners and people from the Law School. They were a way not just of celebrating the visit of the Fellow, but also of Ian's being able to draw together a rather eclectic group of people who otherwise might not talk much to one other at all. Those dinners were a reminder to me that bringing different people together and supporting them was what Ian was about

At his memorial service his cousin David Goddard QC spoke of his and his brother's involvement with their "uncle Ian" as one involving Ian encouraging them to be as good as they possibly could be by treating them as if they already were. This was Ian's involvement with our Review as well. Ian never interfered with the way we ran the Review, except to encourage us to do better. At times, I suspect that we did not make as good a use of his generosity as we could have, but it was his challenge to us, made in a very quiet understated way, that we could always do better next time.

At his memorial service it was revealed that Ian had established a wider trust for the benefit of the legal profession in general. It is my hope that the legal profession will similarly take on the challenge that Ian gave the Law Review.

1 Law Commission The Crown in Court: A Review of the Crown Proceedings Act and National Security Information in Proceedings (NZLC R135, 2015). 
